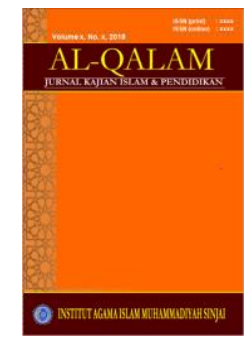

AL-QALAM

Jurnal Kajian Islam \& Pendidikan

Volume 11, No. 1, 2019

ISSN (print) : 1858-4152

ISSN (online) : 2715-5684

Homepage : http://journal.iaimsinjai.ac.id/index.php/al-qalam

\title{
MINAT BELAJAR (Tinjauan Guru Pendidikan Agama Islam)
}

\author{
Jamaluddin ${ }^{1}$, \\ ${ }^{1}$ Institut Agama Islam Muhammadiyah Sinjai, Jln Sultan Hasanuddin No. 20, Sinjai, Sulawesi Selatan \\ jamaluddin.iaim@gmail.com,
}

\begin{abstract}
Abstrak
Minat belajar siswa bukan hanya dipengaruhi dari dalam diri siswa, akan tetapi dipengaruhi pula oleh guru. Peranan guru dalam pendidikan dan pembelajaran merupakan sentral dalam upaya peningkatan minat, kemampuan, dan prestasi siswa. Oleh karena itu, guru sebagai motivator dalam proses pembelajaran harusberusaha meningkatkan kualitasnya, karena berhasil atau tidaknya proses pembelajaran sangat tergantung pada kemampuan dan keprofesionalan guru. Gambaran minat belajar siswa dalam proses pembelajaran Pendidikan Agama Islam yakni adanya keinginan, harapan maupun target-target yang hendak dicapai oleh siswa, sehingga muncul minat yang kuat untuk melakukan sesuatu, termasuk dalam melakukan aktivitas pembelajaran PAI. Dengan demikian upaya dan peran guru dalam mempengaruhi minat belajar siswa diantaranya, guru melakukan pengelolaan kelas dengan baik, membuka dan menutup pembelajaran dengan benar dan efektif, menerapkan metode belajar yang bervariasi, serta penggunaan media belajar dengan tepat.
\end{abstract}

Kata Kunci : Minat Belajar, Guru Pendidikan Agama Islam

\section{Pendahuluan}

Pendidikan dipandang sebagai salah satu aspek yang memiliki peranan pokok dalam membentuk generasi mendatang. Begitu pentingnya pendidikan maka para pengambil kebijakan di Indonesia mengadakan pembaruan sebagai upaya agar pendidikan benar-benar dapat memberikan kontribusi yang signifikan dalam mengikuti irama perkembangan bangsa yang sarat dengan muatan penguasaan iptek (ilmu pengetahuan dan teknologi) dengan parameter imtak (iman dan takwa) agar bisa bahagia di dunia dan selamat di akhirat (Hisyam, 2000: 12).

Keberhasilan dan kegagalan aktifitas pendidikan dan pembelajaran lebih banyak ditentukan oleh aspek substansial, misalnya dana, kualitas guru dan siswa, serta sarana dan prasarana guna mencapai fungsi dan tujuan pendidikan Nasional sebagaimana yang tercantum dalam Undang-Undang RI. No. 20 Tahun 2003 tentang Sistem Pendidikan Nasional:

"Pendidikan nasional berfungsi mengembangkan kemampuan dan membentuk watak serta peradaban bangsa yang bermartabat dalam rangka mencerdaskan kehidupan bangsa, bertujuan untuk berkembangnya potensi siswa agar menjadi manusia yang beriman dan bertakwa kepada Tuhan Yang Maha Esa, berakhlak mulia, sehat, berilmu, cakap, kreatif, mandiri, dan menjadi warga Negara yang demokrasi serta bertanggungjawab" (RI, 2006: 7).

Untuk mencapai tujuan tersebut diperlukan beberapa komponen strategis dalam menjalankan pendidikan di antaranya komponen guru, lingkungan dan manajemen pendidikan (Tilaar). Berarti guru harus meningkatkan peran dan kompetensi dalam menjalankan profesi keguruannya, khususnya dalam rangka meningkatkan minat belajar.

Minat sangat diperlukan karena dengan adanya minat tersebut tujuan belajar akan mudah dicapai. Namun demikian, minat sebagai faktor dari dalam diri sendiri terkadang tidak tumbuh dengan sendirinya, sebab faktor-faktor dari luar juga mempunyai pengaruh terhadap perkembangan minat di dalam diri seseorang. Melihat pentingnya faktor luar dalam memberikan dorongan, maka guru harus 


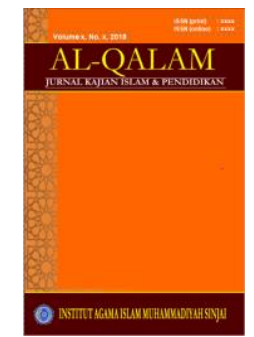

AL-QALAM

Jurnal Kajian Islam \& Pendidikan

Volume 11, No. 1, 2019

ISSN (print) : 1858-4152

ISSN (online) : 2715-5684

Homepage : http://journal.iaimsinjai.ac.id/index.php/al-qalam

mempunyai usaha, metode atau cara terhadap tumbuhnya minat dalam diri siswa untuk mengarahkan dan mengembangkan ke arah tujuan yang ingin dicapainya.

Nurbaeti Sofyan, berpendapat bahwa usaha yang dapat dilakukan untuk membina minat siswa agar menjadi lebih produktif dan efektif antara lain: (1) Memperkaya ide atau gagasan; (2) Memberikan hadiah yang merangsang; (3) Berkenalan dengan orang-orang yang kreatif; (4) Petualangan dalam arti berpetualangan ke alam sekeliling secara sehat; (5) Mengembangkan fantasi; dan (6) Melatih sikap positif (Sofyan, 2004: 9).

Pendapat lain yang dikemukakan oleh Marten Samosir, bahwa untuk memupuk dan meningkatkan minat belajar siswa dapat dilakukan sebagai berikut:

Perubahan dalam lingkungan, kontak, bacaan, hobi dan olahraga, pergi berlibur ke lokasi yang berbeda-beda. Mengikuti pertemuan yang dihadiri oleh orang-orang yang harus dikenal, membaca artikel yang belum pernah dibaca dan membawa hobbi dan olahraga yang beraneka ragam, hal ini akan membuat lebih berminat.

Latihan dan praktek sederhana dengan cara memikirkan pemecahan-pemecahan masalah khusus agar menjadi lebih berminat dalam memecahkan masalah khusus agar menjadi lebih berminat dalam memecahkan persoalan-persoalan.

Membuat orang lain supaya lebih mengembangkan diri yang pada hakekatnya mengembangkan diri sendiri (Samosir, 1992: 112).

Beradasarkan uraian di atas, minat belajar siswa bukan hanya dipengaruhi dari dalam diri siswa, akan tetapi dipengaruhi pula oleh guru. Peranan guru dalam pendidikan dan pembelajaran merupakan sentral dalam upaya peningkatan minat, kemampuan, dan prestasi siswa. Oleh karena itu, guru sebagai motivator dalam proses pembelajaran harusberusaha meningkatkan kualitasnya, karena berhasil atau tidaknya proses pembelajaran sangat tergantung pada kemampuan dan keprofesionalan guru.

\section{Metode}

Berisi jenis penelitian, waktu dan tempat penelitian, target/sasaran, subjek penelitian, prosedur, instrumen dan teknik analisis data serta hal-hal lain yang berkait dengan cara penelitiannya. target/sasaran, subjek penelitian, prosedur, data dan instrumen, dan teknik pengumpulan data, serta teknik analisis data serta hal-hal lain yang berkait dengan cara penelitiannya dapat ditulis dalam subsubbab, dengan sub-subheading. Sub-subjudul tidak perlu diberi notasi, namun ditulis dengan huruf kecil berawalkan huruf kapital, TNR-11 unbold, rata kiri.

Khususnya untuk penelitian kualitatif, waktu dan tempat penelitian perlu dituliskan secara jelas (untuk penelitian kuantitatif, juga perlu). Target/subjek penelitian (untuk penelitian kualitatif) atau populasi-sampel (untuk penelitian kuantitatif) perlu diurai dengan jelas dalam bagian ini. Perlu juga dituliskan teknik memperoleh subjek (penelitian kualitatif) dan atau teknik samplingnya (penelitian kuantitatif).

\subsection{Addsd}

Prosedur perlu dijabarkan menurut tipe penelitiannya. Bagaimana penelitian dilakukan dan data akan diperoleh, perlu diuraikan dalam bagian ini. Untuk penelitian eksperimental, jenis rancangan (experimental design) yang digunakan sebaiknya dituliskan di bagian ini. Macam data, bagaimana data dikumpulkan, dengan instrumen yang mana data dikumpulkan, dan bagaimana teknis pengumpulannya, perlu diuraikan secara jelas dalam bagian ini. 


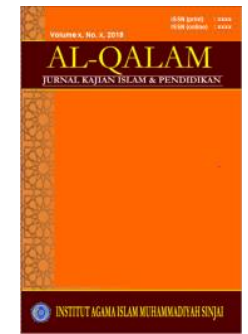

AL-QALAM

Jurnal Kajian Islam \& Pendidikan

Volume 11, No. 1, 2019

ISSN (print) : 1858-4152

ISSN (online) : 2715-5684

Homepage : http://journal.iaimsinjai.ac.id/index.php/al-qalam

\subsection{Xss}

Bagaimana memaknakan data yang diperoleh, kaitannya dengan permasalahan dan tujuan penelitian, perlu dijabarkan dangan jelas. Catatan: Sub-subbab bisa berbeda, menurut jenis atau pendekatan penelitian yang digunakan. Jika ada prosedur atau langkah yang sifatnya sekuensial, jika subbab bukan merupakan judul maka hanya menggunakan huruf. Misalnya sebagai berikut:
a. Poin Satu
b. Poin dua
c. Poin tiga
d. Dan seterusnya.

\section{Hasil dan Pembahasan}

\subsection{Tinjauan tentang Minat Belajar}

a) Pengertian Minat

Secara bahasa minat berarti "kecenderungan hati yang tinggi terhadap sesuatu." (KBBI, 19990:9). Minat adalah suatu rasa lebih suka dan rasa ketertarikan pada suatu hal atau aktifitas, tanpa ada yang menyuruh. Minat pada dasarnya adalah penerimaan akan suatu hubungan antara diri sendiri dengan sesuatu di luar diri. Semakin kuat atau dekat hubungan tersebut, semakin besar minatnya (Slameto, 2010:180). Minat mengandung unsur kognisi (mengenal), emosi (perasaan), dan konasi (kehendak). Oleh sebab itu, minat dianggap sebagai respon yang sadar, sebab jika tidak demikian, minat tidak akan mempunyai arti apa-apa. Unsur kognisi maksudnya adalah minat itu didahului oleh pengetahuan dan informasi mengenai obyek yang dituju oleh minat tersebut, ada unsur emosi karena dalam partisipasi atau pengalaman itu disertai oleh perasaan tertentu, seperti rasa senang, sedangkan unsur konasi merupakan kelanjutan dari unsur kognisi. Dari ketiga unsur inilah yang diwujudkan dalam bentuk kemauan dan hasrat untuk melakukan suatu kegiatan, termasuk kegiatan yang ada di sekolah seperti belajar.

Minat merupakan sifat yang relatif menetap pada diri seseorang. Minat besar sekali pengaruhnya terhadap kegiatan seseorang sebab dengan minat ia akan melakukan sesuatu yang diminatinya. Sebaliknya tanpa minat seseorang tidak mungkin melakukan sesuatu. Sedangkan pengertian minat secara istilah telah banyak

dikemukakan oleh para ahli, di antaranya yang dikemukakan oleh Sardiman, bahwa "minat diartikan sebagai suatu kondisi yang terjadi apabila seseorang melihat ciri-ciri atau arti sementara situasi yang dihubungkan dengan keinginan-keinginan atau kebutuhankebutuhannya sendiri." (Sudirman, 1988: 1995).

Minat sebagai "suatu motif yang menyebabkan individu berhubungan secara aktif dengan sesuatu yang menariknya." (Simanjuntak, 1983: 52). Selanjutnya menurut Zakiah Daradjat, dkk., mengartikan minat adalah "kecenderungan jiwa yang tetap ke jurusan sesuatu hal yang berharga bagi orang." (Zakiah, 1995: 133).

Dari beberapa definisi yang dikemukakan oleh para ahli seperti yang dikutip di atas dapat disimpulkan bahwa, minat adalah kecenderungan seseorang terhadap obyek atau sesuatu kegiatan yang digemari yang disertai dengan perasaan senang, adanya perhatian, dan keaktifan berbuat.

Minat sangat erat hubungannya dengan belajar, belajar tanpa minat akan terasa menjemukan, dalam kenyataannya tidak semua belajar siswa didorong oleh faktor minatnya sendiri, ada yang mengembangkan minatnya terhadap materi pelajaran dikarenakan pengaruh dari gurunya, temannya, orang tuanya. Oleh sebab itu, sudah menjadi kewajiban dan tanggung 


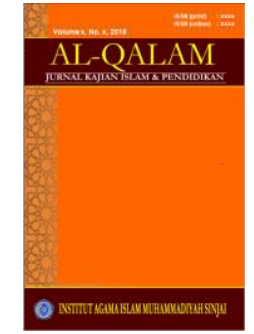

AL-QALAM

Jurnal Kajian Islam \& Pendidikan

Volume 11, No. 1, 2019

ISSN (print) : 1858-4152

ISSN (online) : 2715-5684

Homepage : http://journal.iaimsinjai.ac.id/index.php/al-qalam

jawab sekolah untuk menyediakan situasi dan kondisi yang bisa merangsang minat siswa terhadap belajar. Jadi, yang dimaksud dari minat belajar adalah aspek psikologi seseorang yang menampakkan diri dalam beberapa gejala, seperti : gairah, kemauan, perasaan suka untuk melakukan proses perubahan tingkah laku melalui berbagai kegiatan yang meliputi mencari pengetahuan dan pengalaman, dengan kata lain, minat belajar itu mempunyai ketergantungan pada faktor internal seseorang (siswa) seperti perhatian, kemauan dan kebutuhan terhadap belajar yang ditunjukkan melalui keantusiasan, partisipasi dan keaktifan dalam belajar.

b) Pengertian Belajar

Belajar adalah suatu proses yang kompleks, tidak hanya sekedar menanamkan pengetahuan kepada siswa tetapi banyak hal yang dilakukan pendidik sehingga menyebabkan terjadinya perubahan tingkah laku siswa (Usman, 2002: 21). Abdul Madjid menyatakan bahwa belajar dapat diartikan sebagai suatu proses yang dilakukan oleh pendidik dalam membimbing, membantu, dan mengarahkan siswa untuk memiliki pengalaman belajar (Madjid, 2005: 16).

Muhaimin menyatakan bahwa belajar terkait dengan bagaimana (how to) membelajarkan siswa atau bagaimana membuat siswa dapat belajar dengan mudah dan terdorong oleh kemampuannya sendiri untuk mempelajari apa (what to) yang teraktualisasikan dalam kurikulum sebagai kebutuhan (needs) siswa (Muhaimin, 2004: 146).

Belajar adalah suatu kombinasi yang tersusun meliputi unsur-unsur manusiawi, material, fasilitas, perlengkapan, dan prosedur yang saling memengaruhi mencapai tujuan pembelajaran (Muhaimin, 2004: 146). Unsur-unsur manusiawi yang terlibat dalam sistem pengajaran terdiri atas siswa, guru, dan tenaga kependidikan lainnya, misalnya tenaga administrasi dan tenaga laboratorium. Sedangkan aspek materialnya antara lain buku-buku, papa tulis, sarana belajar seperti media belajar, fotografer, slider, video, OHP dan sebagainya.

Dalam belajar guru harus menciptakan suasana belajar yang dinamis penuh aktivitas, sehingga siswa aktif untuk bertanya, mempertanyakan dan mengemukakan gagasan. Sedangkan belajar merupakan proses aktif dari siswa dalam membangun pengetahuan dan keterampilan. Deskripsi ini menggambarkan bahwa belajar merupakan proses kegiatan secara sadar yang dilakukan oleh guru dengan menciptakan suasana belajar bagi siswa secara dinamis penuh aktivitas, sehingga siswa dapat memahami materi pembelajaran.

c) Faktor yang mempengaruhi minat belajar

Minat belajar tiap-tiap siswa tidak sama, ketidaksamaan itu disebabkan oleh banyak hal mempengaruhi minat belajar, sehingga ia dapat belajar dengan baik atau sebaliknya gagal sama sekali. Ada siswa yang minatnya tinggi dan ada juga yang rendah. Hal tersebut akan sangat memengaruhi aktivitas dan hasil belajarnya dalam mata pelajaran Pendidikan Agama Islam. Adapun faktor-faktor yang memengaruhi minat belajar siswa, secara garis besar dapat diklasifikasikan menjadi dua, yaitu:

1. Faktor intern

$>$ Kondisi fisik/jasmani siswa saat mengikuti pelajaran Kondisi fisik atau jasmani siswa saat mengikuti pelajaran Pendidikan Agama Islam sangat berpengaruh terhadap minat dan aktivitas belajarnya. Faktor kesehatan badan, seperti kesehatan yang prima dan tidak dalam keadaan sakit atau lelah, akan sangat membantu dalam memusatkan perhatian terhadap pelajaran. Sebab pelajaran Pendidikan Agama Islam memerlukan kegiatan mental yang tinggi, menuntut banyak perhatian dan pikiran jernih. Oleh karena itu apa bila siswa mengalami kelelahan atau terganggu kesehatannya, akan sulit memusatkan perhatiannya dan berpikir jernih (Pendidiksn Nasional, 2003: 6).

> Pengalaman belajar Pendidikan Agama Islam di jenjang pendidikan sebelumnya Pengalaman belajar sangat berkaitan dengan kemampuan awal. Sebagaimana yang dikemukakan oleh Bloom, "kemampuan awal adalah pengetahuan, keterampilan dan 


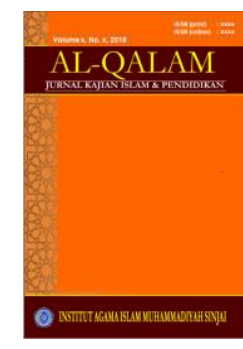

AL-QALAM

Jurnal Kajian Islam \& Pendidikan

Volume 11, No. 1, 2019

ISSN (print) : 1858-4152

ISSN (online) : 2715-5684

Homepage : http://journal.iaimsinjai.ac.id/index.php/al-qalam

kompetensi, yang merupakan prasyarat yang dimiliki untuk dapat mempelajari suatu pelajaran baru atau lebih lanjut (Nashar, 20004: 64).

Setiap siswa masing-masing telah memiliki berbagai pengalaman belajar yang berbeda-beda yang diperolehnya di jenjang pendidikan sebelumnya. Hal tersebut merupakan modal awal bagi siswa dalam melakukan kegiatan belajar selanjutnya. Pengalaman belajar yang telah dimiliki oleh siswa besar pengaruhnya terhadap minat belajar. Pengalaman tersebut menjadi dasar untuk menerima pengalaman-pengalaman baru yang akan sangat membantu dalam minat belajar siswa. Sebagai contoh, seseorang siswa akan sangat mudah dalam menguasai dan memahami materi pelajaran Pendidikan Agama Islam, karena ia telah memahami dan menguasai dengan baik materi pelajaran Pendidikan Agama Islam sewaktu di SD/MI. Jadi, dapat dipahami bahwa pengalaman belajar Pendidikan Agama Islam di jenjang pendidikan sebelumnya turut berpengaruh terhadap belajar siswa, terutama dalam mata pelajaran Pendidikan Agama Islam.

\section{Faktor Eksternal}

$>$ Metode dan gaya mengajar guru Pendidikan Agama Islam

Metode dan gaya mengajar guru juga memberi pengaruh terhadap minat siswa dalam belajar Pendidikan Agama Islam. Oleh karena itu hendaknya guru dapat menggunakan metode dan gaya mengajar yang dapat menumbuhkan minat dan perhatian siswa. Dominikus Catur Raharja menyatakan: Guru adalah kreator proses belajar mengajar. Guru adalah orang yang akan mengembangkan suasana bebas bagi siswa untuk mengkaji apa yang menarik minatnya, mengekspresikan ide-ide dan kreativitasnya dalam batas-batas norma-norma yang ditegakkan secara konsisten (Rahja, 2001: 7).

Cara penyampaian pelajaran yang kurang menarik menjadikan siswa kurang berminat dan kurang bersemangat untuk mengikutinya. Namun sebaliknya, jika pelajaran disampaikan dengan cara dan gaya yang menarik perhatian, maka akan menjadikan siswa tertarik dan bersemangat untuk selalu mengikutinya dan kemudian mendorongnya untuk terus mempelajarinya. Cara seorang guru dalam menyampaikan pelajaran sangat terkait dengan tipe atau karakter kepribadiannya, seperti yang di kemukakan Muhibin Syah, sebagai berikut

1) Guru yang otoriter (Autoriterian) Secara harfiah, otoriter berarti berkuasa sendiri atau sewenang-wenang. Dalam belajar, guru yang otoriter mengarahkan dengan keras segala aktivitas para siswa tanpa dapat ditawar-tawar. Hanya sedikit sekali kesempatan yang diberikan kepada siswa untuk berperan serta memutuskan cara terbaik untuk kepentingan belajar mereka, sehingga antara guru dan murid tidak terdapat hubungan yang akrab.

2) Guru Laissez-Faire (Lezeifee) Padanannya adalah individualisme (paham yang menghendaki kebebasan pribadi). Guru yang berwatak ini biasanya gemar mengubah arah dan cara pengelolaan pembelajaran secara seenaknya, sehingga menyulitkan siswa dalam mempersiapkan diri. Sebenarnya guru tersebut tidak menyenangi profesinya sebagai tenaga pendidik meskipun ia memiliki kemampuan yang memadai.

3) Guru yang demokratis, arti demokratis adalah bersifat demokratis yang pada intinya mengandung makna memperhatikan persamaan hak dan kewajiban semua orang. Guru yang memiliki sifat ini pada umumnya dipandang sebagai guru yang paling baik dan ideal. Alasannya, dibanding dengan guru yang lainnya guru tipe demokratis lebih suka bekerjasama dengan rekan-rekan seprofesinya, namun tetap menyelesaikan tugasnya secara mandiri. Ditinjau dari sudut hasil pengajaran, guru yang demokratis dengan yang otoriter tidak jauh berbeda. Akan tetapi dari sudut moral, guru yang demokratis dan karenanya ia lebih disenangi oleh rekan-rekan sejawatnya maupun oleh para siswanya sendiri. 
4) Guru yang otoritatif (Authoritative). Otoritatif berarti berwibawa karena adanya kewenangan baik berdasarkan kemampuan maupun kekuasaan yang diberikan. Guru yang otoritatif adalah guru yang memiliki dasar-dasar pengetahuan baik pengetahuan bidang studi faknya maupun pengetahuan umum. Guru seperti ini biasanya ditandai oleh kemampuan memerintah secara efektif kepada para siswa dan kesenangan mengajak kerja sama kepada para siswa bila diperlukan dalam mengikhtiarkan cara terbaik untuk penyelenggaraan pembelajaran. Namun, dalam hal memerintah atau memberi anjuran, guru yang otoritatif pada umumnya lebih efektif, karena lebih disegani oleh para siswa dan dipandang sebagai pemegang otoritas ilmu pengetahuan paknya (Syah, 2009:253).

Tersedianya fasilitas dan alat penunjang pelajaran Pendidikan Agama Islam

Fasilitas dan alat dalam belajar memiliki peran penting dalam memotivasi minat siswa pada suatu pelajaran. Tersedianya fasilitas dan alat yang memadai dapat memancing minat siswa pada mata pelajaran Pendidikan Agama Islam. Fasilitas dan alat penunjang pelajaran Pendidikan Agama Islam yang dimaksud berupa:

1) Alat dan fasilitas yang digunakan bersama-sama dengan murid. Sebagai contoh, papan tulis, kapur tulis/spidol, ruangan kelas dan sebagainya.

2) Alat yang dimiliki oleh masing-masing murid dan guru. Misalnya : alat tulis, buku pelajaran Pendidikan Agama Islam, buku pengangan guru dan lain sebagainya.

3) Alat peraga yang berfungsi untuk memperjelas atau member gambaran yang lebih jelas tentang hal-hal yang diajarkan. Belajar dengan menggunakan fasilitas dan alat lebih efektif dan lebih menyenangkan dibandingkan tanpa menggunakan alat peraga atau hanya dengan teori saja.

Situasi dan kondisi lingkungan

Situasi dan kondisi lingkungan turut memberi pengaruh terhadap minat belajar siswa dalam pelajaran. Faktor situasi dan kondisi lingkungan yang dimaksud di sini adalah faktor situasi dan kondisi saat siswa melakukan aktivitas belajar Pendidikan Agama Islam di sekolah, baik fisik ataupun sosial. Faktor kondisi lingkungan fisik termasuk di dalamnya adalah seperti keadaan suhu, kelembaban, kepengapan udara, pencahayaan dan sebagainya. Belajar Pendidikan Agama Islam pada keadaan udara yang segar, akan lebih baik hasilnya dari pada belajar dalam keadaan udara yang panas dan pengap, atau belajar pagi hari akan lebih baik dari pada belajar siang hari. Jadi, minat dan perhatian siswa akan lebih baik jika jam pelajaran Pendidikan Agama Islam di letakkan di pagi hari.

Kondisi lingkungan sosial yang lain, seperti suara mesin pabrik, hiruk-pikuk lalu lintas, gemuruh pasar dan sebagainya, juga berpengaruh terhadap konsentrasi dan perhatian siswa saat belajar Pendidikan Agama Islam. Karena itulah disarankan hendaknya lingkungan sekolah agar didirikan jauh dari pabrik, keramaian lalu lintas dan pasar.

\subsection{Tinjauan tentang Guru Pendidikan Agama Islam}

\section{a. Pengertian Guru}

Guru adalah semua orang yang berwenang dan bertanggung jawab terhadap pendidikan, dan membimbing serta membina murid-murid, baik secara individual maupun secara klasikal, baik di sekolah maupun di luar sekolah (Sardiman, 2001: 123). Latar belakang pendidikan seorang guru dari guru lainnya terkadang tidak sama dengan pengalaman pendidikan yang pernah dimasuki selama jangka waktu tertentu. Perbedaan latar belakang pendidikan akan memengaruhi kegiatan guru dalam melaksanakan kegiatan interaksi belajar mengajar. Tetapi, karena banyaknya guru yang dibutuhkan di madrasah-madrasah maka latar belakang pendidikan seseorang seringkali tidak dipertimbangkan.

Latar belakang pendidikan seorang guru dari guru lainnya terkadang tidak sama dengan pengalaman pendidikan yang pernah dimasuki selama jangka waktu tertentu. Perbedaan latar belakang pendidikan akan memengaruhi kegiatan guru dalam melaksanakan 


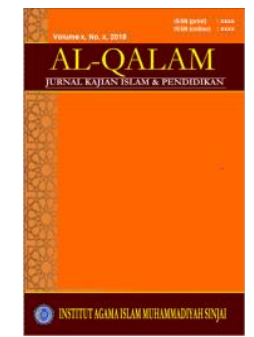

AL-QALAM

Jurnal Kajian Islam \& Pendidikan

Volume 11, No. 1, 2019

ISSN (print) : 1858-4152

ISSN (online) : 2715-5684

Homepage : http://journal.iaimsinjai.ac.id/index.php/al-qalam

kegiatan interaksi belajar mengajar. Tetapi, karena banyaknya guru yang dibutuhkan di madrasah-madrasah maka latar belakang pendidikan seseorang seringkali tidak dipertimbangkan.

Guru merupakan tenaga pendidik yang mempunyai tugas pokok melaksanakan kegiatan belajar mengajar. Tugas guru tidaklah ringan karena harus meningkatkan kualitas sumber daya manusia sesuai standar kompetensi tertentu serta norma dan nilai-nilai yang berlaku. Dalam aspek instruction, guru bertugas menstranfer pengetahuan dan keterampilan sesuai dengan kurikulum yang berlaku. Dalam tugas instruction ini, guru berfungsi untuk meningkatkan pengetahuan dan keterampialn siswa sehingga kelak akan menjadi orang memiliki pengetahuan yang buas serta keterampilan yang tinggi (Djamarah, 2000: 32).

Guru harus pandai-pandai memberikan motivasi kepada siswanya agar siswa bersedia dengan senang hati mengembangkan dan memperluas pengetahuan dan keterampilan yang diberikan di kelas dengan memanfaatkan sumber-sumber informasi yang ada baik dari informasi media cetak maupun elektronik. Oleh sebab itu, menurut pendapat penulis guru yang berhasil adalah guru yang mampu mendorong anak didik untuk secara terus menerus belajar, mencari ilmu dan pengetahuan baru sehingga pengetahuan dan keterampilan yang ada selalu berkembang serta mampu mengatasi permasalahan yang dihadapi dengan menggunakan pengetahuan dan keterampilan yang telah dimilikinya.

Dalam realita banyak guru yang pintar tetapi tidak mampu membuat siswanya menjadi pintar. Dalam aspek education, guru bertugas untuk membentuk manusia yang memiliki nilai-nilai luhur sesuai dengan norma dan nilai yang tersirat dalam falsafah negara serta perkembangan masyarakat yang berlaku. Oleh sebab itu, selain guru berfungsi untuk melestarikan dan mengembangkan nilai luhur kepribadian bangsa guru harus menanamkan sikap kedisiplinan, kreativitas dan inovasi. Jika sebagian besar penduduk Indonesia memiliki motif berprestasi yang tinggi, besar kemungkinan akan mampu mengejar ketertinggalannya dan bahkan kemungkinan besar akan mampu mencapai posisi yang sejajar dengan negaranegara maju dengan tetap memegang teguh nilai-nilai luhur sesuai dengan kepribadian Bangsa Indonesia.

b. Pengertian Pendidikan Agama Islam

Pendidikan agama Islam dengan pendidikan Islam, kedua istilah ini dianggap sama, sehingga tatkala seseorang berbicara tentang pendidikan Islam ternyata isinya terbatas pada pendidikan agama Islam, atau sebaliknya ketika seseorang berbicara tentang pendidikan agama Islam justru yang dibahas di dalamnya adalah tentang pendidikan Islam. Padahal kedua istilah ini memiliki substansi yang berbeda (Muhaimin, 2006: 4).

Pendapat tersebut di atas memberikan gambaran bahwa pendidikan Islam adalah pendidikan yang dilandasi dan dibingkai oleh nilai-nilai ajaran Islam dalam rangka mengembangkan seluruh potensi yang dimiliki oleh siswa baik fisik maupu psikhis agar tumbuh menjadi manusia yang bertanggungjawab, cerdas dan cakap dalam mengamalkan tanggung jawab kekhalifahannya dalam rangka mendapatkan kebahagiaan dunia dan akhirat.

Dalam konteks kajian atau penelitian untuk pengembangan pendidikan Islam, Azyumardi Azra mengemukakan bahwa pola kajian kependidikan Islam di Indonesia sebagaimana yang terdapat dalam literatur yang tersedia, selama ini lebih banyak berfokus pada tiga kategori, yaitu: 1) kajian-kajian sosio historis pendidikan Islam; 2) kajian pemikiran dan teori kependidikan Islam; 3) kajian metodologis pendidikan Islam (Azra, 1999: 86).

Abdul Rachman Shaleh mendefinisikan pendidikan Islam sebagai usaha sadar untuk mengarahkan pertumbuhan dan perkembangan siswa dengan segala potensi yang dianugrahkan oleh Allah swt, kepadanya, agar mampu mengemban amanah dan tanggung jawab sebagai khalifah Allah swt di bumi dalam pengabdiannya kepada Allah swt. (Shaleh, 2001: 4). 


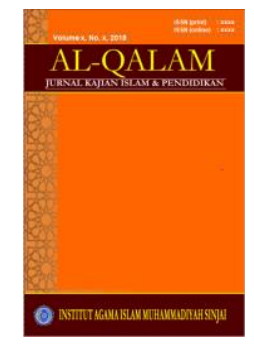

AL-QALAM

Jurnal Kajian Islam \& Pendidikan

Volume 11, No. 1, 2019

ISSN (print) : 1858-4152

ISSN (online) : 2715-5684

Homepage : http://journal.iaimsinjai.ac.id/index.php/al-qalam

Pendidikan Islam itu sebagai sebuah proses yang dilakukan untuk menciptakan manusia-manusia yang seutuhnya beriman dan bertakwa kepada Tuhan yang Maha Esa serta mampu mewujudkan eksistensinya sebagai khalifah Allah di muka bumi, yang berdasarkan kepada ajaran al-Quran dan Sunnah Nabi saw. (Arief, 2002: 16). Jika dikaitkan dengan pengertian pendidikan Islam di atas, maka kajian pemikiran dan teori terkait dengan pengertian pendidikan Islam yang pertama; kajian metodologis terkait dengan pengertian pendidikan Islam yang kedua; kajian sosio historis terkait dengan pengertian pendidikan Islam yang ketiga kajian metodologis pendidikan Islam.

Dalam pedoman pendidikan agama Islam di sekolah umum disebutkan pengertian pendidikan agama Islam adalah usaha sadar dan terencana dalam menyiapkan siswa untuk mengenal, mamahami, menghayati, mengamalkan hingga mengimani ajaran agama Islam, dibarengi dengan tuntunan untuk menghormati penganut agama lain dalam hubungannya dengan kerukunan antar umat beragama dalam masyarakat untuk mewujudkan persatuan nasional (Muhaimin, 2002: 76).

Pendidikan agama Islam adalah sebagai suatu proses ikhtiar yang mengandung kerakteristik dan watak khusus, yaitu proses penanaman yang menjadi fundamental spiritual dalam kehidupan sehari-hari menurut kaidah-kaidah agamanya. Nilai-nilai keimanan yang menjadi fundamental spriritual manusia dari sikap dan tingkah lakunya direfleksikan dalam kehidupan sehari-hari menurut kaidah-kaidah agamanya. Nilai-nilai keimanan seseorang adalah keseluruhan pribadi yang menyatakan dalam bentuk tingkah laku lahiriyah dan rohaniayah dan merupakan tenaga/penegak yang fundamental bagi tingkah laku seseorang (Arifin, 2000: 214).

Pendidikan agama Islam pada hakikatnya adalah usaha orang dewasa muslim bertakwa secara sadar mengarahkan dan membimbing pertumbuhan serta perkembangan fitrah (kompetensi dasar) anak didik melalui ajaran Islam ke arah titik maksimal pertumbuhan dan perkembangannya (Arifin, 2000: 32). Zakiah Daradjat mengemukakan bahwa pendidikan agama Islam adalah:

1. Usaha berupa bimbingan dan asuhan terhadap anak didik agar kelak setelah selesai pendidikannya dapat memahami dan mengamalkan ajaran agama Islam serta menjadikannya sebagai pandangan hidup (way of life).

2. Pendidikan yang dilaksanakan berdasar ajaran Islam.

3. Pendidikan dengan melalui ajaran agama Islam, yaitu berupa bimbingan dan asuhan terhadap anak didik agar nantinya setelah selesai dari pendidikan ia dapat memahami, menghayati dan mengamalkan ajaran-ajaran agama Islam yang telah diyakininya secara menyeluruh, serta menjadikan ajaran agama Islam itu sebagai suatu pandangan hidupnya demi keselamatan dan kesejahteraan hidup di dunia maupun di akhirat kelak (Daradjat, 2000: 86).

Samsul Nizar mengatakan bahwa pendidikan agama Islam adalah suatu sistem yang memungkinkan seseorang (siswa) dapat mengarahkan kehidupannya sesuai ideologi Islam, melalui pendekatan ini, ia akan dapat dengan mudah membentuk kehidupan dirinya sesuai dengan nilai-nilai ajaran Islam yang diyakininya (Nizar, 2002: 32).

Pendidikan Islam bagi Ahmad Tafsir ialah bimbingan yang diberikan oleh seseorang kepada seseorang agar ia berkembang secara maksimal sesuai dengan ajaran Islam. Bila disingkat, pendidikan Islam ialah bimbingan terhadap seseorang agar ia menjadi Muslim semaksimal mungkin (Tafsir, 2005: 32).

Berdasarkan pengertian tentang pendidikan agama Islam yang dikemukakan oleh para pakar di atas maka yang dimaksudkan dengan pendidikan agama Islam adalah upaya sadar dan terencana orang dewasa muslim berdasar al-Quran dan hadis untuk membimbing dan melatih pertumbuhan intelek yang memiliki iman, takwa, budi pekerti luhur, dan skill dan dapat mengimplementasikan dalam kehidupan sehari-harinya baik hubungan kepada Allah 


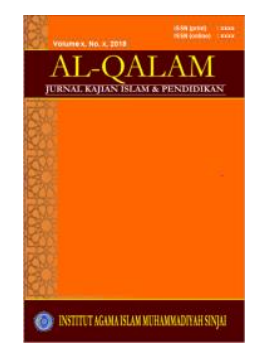

AL-QALAM

Jurnal Kajian Islam \& Pendidlikan

Volume 11, No. 1, 2019

ISSN (print) : 1858-4152

ISSN (online) : 2715-5684

Homepage : http://journal.iaimsinjai.ac.id/index.php/al-qalam

swt maupun hubungan dengan manusia. Kegiatan pendidikan harus berisikan interaksi antara sipendidik dengan siterdidik. Sipendidik dapat mengambil wujud sebagai guru, pembimbing, pemimpin, orang tua, dan sebagainya.

\section{Simpulan}

Gambaran minat belajar siswa dalam proses pembelajaran Pendidikan Agama Islam yakni adanya keinginan, harapan maupun target-target yang hendak dicapai oleh siswa, sehingga muncul minat yang kuat untuk melakukan sesuatu, termasuk dalam melakukan aktivitas pembelajaran PAI. Dengan demikian upaya dan peran guru dalam mempengaruhi minat belajar siswa diantaranya, guru melakukan pengelolaan kelas dengan baik, membuka dan menutup pembelajaran dengan benar dan efektif, menerapkan metode belajar yang bervariasi, serta penggunaan media belajar dengan tepat.

\section{Ucapan Terimakasih}

Bagian ini sifatnya pilihan, boleh tidak ada (optional). Ucapan terima kasih biasanya diberikan karena bantuan penulisan yang dipandang berpengaruh besar atau pun bantuan dana untuk melakukan penelitian.

\section{Daftar Pustaka}

Penyusunan Daftar Pustaka yang mengikuti teknik yang standar harus dilakukan secara baku dan konsisten. Daftar pustaka hanya memuat pustaka yang disitasi. Sitasi dituliskan dengan menggunakan model American Psychological Association 6th Edition (APA Style). Contoh penulisan daftar pustaka sebagai berikut:

Abdul Madjid, Perencanaan Pembelajaran (Mengembangkan Standar Kompetensi Pendidik), Cet. I; Bandung: Rosda Karya, 2005.

Abdul Rachman Shaleh, Pendidikan Agama dan Keagamaan, Visi, Misi dan Aksi, Cet. II; Jakarta: PT Gema Windu Pancaperkasa, 2001.

Armai Arief, Pengantar Ilmu dan Metodologi Pendidikan Islam, Cet. I; Jakarta: Ciputat Pers, 2002.

Ahmad Tafsir, Ilmu Pendidikan Dalam Perspektif Islam, Cet. VI; Bandung: PT. Remaja Rosdakarya, 2005.

Azyumardi Azra, Pendidikan Islam: Tradisi dan Modernisasi Menuju Milenium Baru, Cet. I Jakarta: Logos, 1999.

Basyiruddin Usman, Metodologi Pembelajaran Agama Islam, Cet. I; Jakarta: Ciputat Pers, 2002.

Djamarah, Prestasi Belajar dan Kompetensi Guru, Surabaya:Usahan Nasional. 2000.

Dominikus Catur Raharja, "Kesesuaian Pendidikan Bakat Menentukan Prestasi Siswa”, Jakarta, 2001.

Departemen Pendidikan Nasional, Standar Kompetensi Mata Pelajaran Pendidikan Agama Islam SMPN, Jakarta: Pusat Kurikulum Balitbang Depdiknas, 2003.

H.A.R. Tilaar, Paradigma Baru Pendidikan Nasional, Cet. I; Jakarta: Rineka Cipta, 2000. 


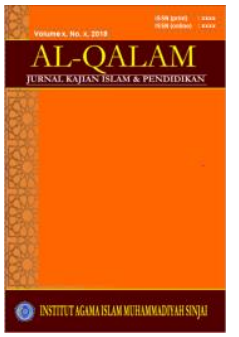

AL-QALAM

Jurnal Kajian Islam \& Pendidikan

Volume 11, No. 1, 2019

ISSN (print) : 1858-4152

ISSN (online) : 2715-5684

Homepage : http://journal.iaimsinjai.ac.id/index.php/al-qalam

L. Pasaribu dan Simanjuntak, Proses Belajar Mengajar, Bandung: Tarsito, 1983.

M. Arifin, Kapita Selekta Pendidikan: Islam dan Umum, Cet. IV; Jakarta: PT. Bumi Aksara, 2000.

M. Arifin, Ilmu Pendidikan Islam; Suatu Tinjauan Teoritis dan Praktis Berdasarkan Pendekatan Interdisipliner, Cet; V; Jakarta: Bumi Aksara, 2000.

Muhaimin, Paradigma Pendidikan Islam, Upaya Mengefektifkan Pendidikan Agama Islam di Sekolah, Cet. II; Bandung: Remaja Rosdakarya, 2002.

Muhaimin, et al, Paradigma Pendidikan Islam, Upaya Mengefektifkan Pendidikan Agama Islam di Sekolah, Cet. III; Bandung: Remaja Rosda Karya Offset, 2004.

Muhaimin, Nuansa Baru Pendidikan Islam, Mengurai Benang Kusut Dunia Pendidikan, Cet. I; Jakarta: RajaGrafindo Persada, 2006.

Muhibin Syah, Psikologi Pendidikan dengan Pendekatan Baru, Bandung: Remaja Rosda Karya, 2009.

Marten Samosir, Seni Berpikir Kreatif, Jakarta: Erlangga, 1992.

Nurbaeti Sofyan, Hubungan antara Minat dan Perhatian dengan Prestasi Belajar Siswa, Bandung: PT. Citra Umbaran, 2004.

Nashar, Peranan Motivasi dan Kemampuan Awal dalam Kegiatan Belajar Mengajar, Cet. ke-2; Jakarta: Delia Press, 2004).

Rebublik Indonesia, Undang-Undang No. 20 tentang Sistem Pendidikan Nasional, Bandung: PT. Citra Umbaran, 2006.

Sardiman, Interaksi dan Motivasi Belajar Mengajar, Jakarta: Rajawali, 2001.

Samsul Nizar, Filsafat Pendidikan Islam, Pendekatan Historis, Teoritis dan Praktis, Cet. I; Jakarta: Ciputat Pers, 2002.

Slameto, Belajar dan Faktor-Faktor yang Mempengaruhinya, Jakarta: Rinelka Cipta, 2010.

Suyanto dan Djihad Hisyam, Pendidikan di Indonesia Memasuki Milenium III, Jogyakarta: Adi Cita Karya Nusa, 2000.

Tim Penyusun Kamus Pusat Pengembangan dan Pembinaan Bahasa, Kamus Besar Bahasa Indonesia, Jakarta: Balai Pustaka, 1990.

Zakiah Daradjat, dkk, Ilmu Pendidikan Islam, Cet. IV; Jakarta: PT. Bumi Aksara, 2000. 